J. Dairy Sci. 103:5791-5791

https://doi.org/10.3168/jds.2020-103-6-5791

(๑) American Dairy Science Association ${ }^{\circledR}, 2020$.

\title{
Corrigendum to "Annual rhythms of milk synthesis in dairy herds in 4 regions of the United States and their relationships to environmental indicators" (J. Dairy Sci. 103:3696-3707)
}

\section{J. Salfer, P. A. Bartell, C. D. Dechow, and K. J. Harvatine}

In the supplemental tables for this paper (https://doi.org/10.3168/jds.2019-17362), the adjustment factors were not standardized in the same way. Revised supplemental tables are now available online.

The authors regret the errors.

\section{REFERENCES}

Salfer, I. J., P. A. Bartell, C. D. Dechow, and K. J. Harvatine. 2020. Annual rhythms of milk synthesis in dairy herds in 4 regions of the United States and their relationships to environmental indicators. J. Dairy Sci. 103(4):3696-3707. https://doi.org/10.3168/jds.2019-17362. 